\title{
ADVERSE EFFECTS IN WORKERS EXPOSED TO INORGANIC LEAD
}

\author{
Sašo STOLESKI ${ }^{1}$, Jovanka KARADŽINSKA-BISLIMOVSKA ${ }^{1}$, Elisaveta STIKOVA², \\ Snežana RISTESKA-KUC ${ }^{1}$, Dragan MIJAKOSKI ${ }^{1}$, and Jordan MINOV ${ }^{1}$ \\ Institute of Occupational Health - WHO Collaborating Center for Occupational Health ${ }^{1}$, Republic Institute for \\ Health Protection², Skopje, Macedonia \\ Received in December 2007 \\ Accepted in February 2008
}

\begin{abstract}
This paper describes a retrospective cohort study comparing 60 workers occupationally exposed to inorganic lead and 60 matched controls. All subjects were assessed using data obtained from a specially designed Questionnaire for lead exposure and toxic effects assessment, physical examination, spirometry, ECG, and laboratory tests including blood lead level (BLL) and biomarkers of lead toxic effects. Muscle pain, droopiness, and work-related nasal symptoms were significantly more frequent in lead workers. The prevalence of lung symptoms was higher in lead workers than in controls, but not significantly ( $20 \%$ vs. $6.6 \%$, respectively). Mean values of BLL and $\delta$-aminolevulinic acid (ALA) were significantly higher in lead workers. The activity of $\delta$-aminolevulinic acid dehydratase (ALAD) in lead workers was significantly lower than in controls. Abnormal of BLL, ALAD, and ALA were more frequent in lead workers, with statistical difference for BLL and ALAD. Inverse correlation was found between BLL and ALAD, and positive correlation between BLL and age, years of employment, and years of exposure. Inverse correlation was found between ALAD and age, years of employment, years of exposure, blood pressure, alcohol consumption, and years of alcohol consumption. Changes in spirometry correlated inversely with BLL. A positive correlation was found between BLL and erythrocyte count and haemoglobin concentration, whereas it was inverse for ALAD and haemoglobin concentration. A significant difference was found for BLL and ALAD, with a very high odds ratio (14.64 and 7.23, respectively) and high relative risk (4.18 and 3.08, respectively). Our data have confirmed the association between occupational lead exposure and deviation in specific biological markers of lead effect and between the role of occupational exposure in the development of adverse effects.
\end{abstract}

KEY WORDS: ALA, ALAD, biological markers, blood lead, occupational exposure, toxicity, $\delta$ aminolevulinic acid dehydratase

Lead is a natural constituent of the earth's crust, but once mined and transformed into manmade products, lead becomes highly toxic (1). Lead dispersed through gasoline exhausts, smelter emissions, and paint removers never fully disappears from our environment nor has the man evolved a good biological system to offer any protection from it (2). The contact with lead and its compounds within different conditions and circumstances can result in acute, sub-acute, and chronic occupational lead poisoning, present in the process of lead production and use or in non-occupational lead poisoning, present in everyday life through emissions by lead smelting plants, exhausts by motors running on ethyl fuel, and through soil via food or drinking water (3). Since lead has been phased out as a gasoline additive (tetraethyl lead) since the 1970s and its use in paint and food containers has been curtailed, blood lead concentrations have decreased significantly in general population, but other sources of lead and its unknown toxicity threshold continue to make lead an issue of public health. (4). The beginning of production in the 
lead smelting plant "MHK Zletovo" in the municipality of Veles in 1972 gave rise to issues related to occupational exposure to inorganic lead. Occupational lead exposure mostly occurs in lead smelting plants and battery factories, as well as in renovation of old houses, when workers inhale or ingest fumes and dust contaminated with lead. Occupational risk exists where lead and its compounds are present in the form of vapour or aerosol (lead fume, lead dust) in the working environment, especially in lead ore smelting $(5,6)$. The only larger complex in Macedonia which is an important source of lead pollution is the lead and zinc smelting plant in Veles with estimated lead emission of 83 tonnes per year according to the 1996 National Environmental Action Plan (NEAP) (3). The average lead emission in Macedonia in 2003 was 16 $g$ per resident (3). Occupational lead poisoning is almost without exception chronic and occurs after exposure of several weeks or months (7). Lead is one of the best-studied toxic substances (8), with very low levels of detection (9), and is a confirmed multi-target toxicant with effects in the gastrointestinal, haematopoietic, cardiovascular, nervous, immune, and reproductive system and the kidneys (10-13). Blood lead level (BLL) is most frequently used bioindicator of recent lead exposure (14), the most appropriate indicator of actual (present) or previous permanent lead exposure, but also a good indicator of lead body burden. Biological markers of lead effects are the activity of $\delta$-aminolevulinic acid dehydratase (ALAD), free erythrocyte protoporphyrin (FEP), pirimidin-5'nucleotidase in erythrocytes, and the concentration of aminolevulinic acid (ALA) and coproporphyrin in urine (15). At an average or high lead exposure FEP and zinc protoporphyrine (ZPP) concentrations increase, but are not sufficiently sensitive or specific to be primary indicators of lead effects $(16,17)$. The lowest observed adverse effect level (LOAEL) is a health-based level of concern (18). According to the US Food and Drug Administration (US FDA) the LOAEL for blood lead concentration is $100 \mu \mathrm{g} \mathrm{L}^{-1}$ in children and foetuses and $300 \mu \mathrm{g} \mathrm{L}^{-1}$ in adults (19). Lead inhibits three enzymes in the haem biosynthesis (ALAD, coporphyrinogen oxidase, and ferrochelatase), but its effects on ALAD are most profound (20). As erythrocyte ALAD activity is inhibited, ALA levels in blood increase, leading also to elevated levels of ALA in the urine. The threshold for detecting elevated blood and urinary ALA levels is $400 \mu \mathrm{g} \mathrm{L}^{-1}$, but may be as low as $150 \mu \mathrm{g} \mathrm{L}^{-1}$ to $200 \mu \mathrm{g} \mathrm{L}^{-1}$. Increased coproporphyrin levels are elevated in individuals with blood lead concentrations of $400 \mu \mathrm{g} \mathrm{L}^{-1}$ (21). ALAD is one of the most sensitive indicators of lead effect with the threshold BLL of less than $100 \mu \mathrm{g} \mathrm{L}^{-1}$. In her study of occupational lead exposure in the smelting plant in Veles in 1997, Isjanovska found a statistically significant difference between average ALAD blood values in the exposed and unexposed workers $(p<0.001)(6)$. Results of a 2004 study on lead exposure conducted by the Institute of Occupational Health of Skopje showed a higher frequency of abnormal ALAD in lead workers from a smelting plant $(58.5 \%)$, than in urban adult population without occupational exposure $(14 \%$; $\mathrm{p}<0.001)$ (22). Occupational exposure to inorganic lead is still a burning issue in metal production and certain aspects of lead toxicity have still not been clarified. The aim of this study was to identify the association between occupational exposure to lead and abnormalities in specific biomarkers of lead effect, to determine the role of occupational exposure in the development of lead-related adverse effects development, haematopoesis in particular, and to establish factors that may modifying the expression of lead toxicity.

\section{SUBJECTS AND METHODS}

\section{Study design}

A retrospective cohort study was carried out in two groups differing in risk and exposure to lead at the Institute of Occupational Health, Skopje WHO Collaborating Center from November 2004 to December 2006. All subjects were assessed using a specially designed Questionnaire for the assessment of lead exposure and toxic effects, aimed at early detection of health damage caused by lead. All study subjects underwent physical examination and laboratory and toxicology tests. The influence of sex on the study results was not evaluated.

\section{Questionnaire for lead exposure and toxic effects assessment}

For the research purposes we have used a specially designed questionnaire that was filled in by a medical doctor, and contained data about demographics, accompanying diseases, work history (occupation, workplace, duration of exposure, and total duration of employment, previous workplace, if any, and duration, hazards at the workplace), smoking status (active smoker, ex-smoker, non-smoker, number of cigarettes 
per day, duration of smoking), alcohol consumption (quantity and frequency), risk information, work organization, absenteeism, medical and family history, work-relatedness of the symptoms, and use of preventive measures. The questionnaire was useful for obtaining data about specific occupational risks and health status in the exposed workers, association between lead exposure and abnormalities in specific lead biomarkers, lead toxic effects and possible modifying factors for their expression. This questionnaire was carried out in the municipality of Veles within a comprehensive preventive programme of occupational and environmental toxicology of heavy metals, supported by the Ministry of Health of the Republic of Macedonia.

\section{Subjects}

The exposed group (Group I) consisted of 60 lead workers of the smelting plant of Veles, who worked in lead production and refining (occupationally exposed to inorganic lead); 51 were men and nine women, with the following averages: age $=(45.1 \pm 7.6)$ years, total employment duration $=(22.8 \pm 9.2)$ years, exposure duration or years on the current workplace $=(19.2 \pm 7.8)$ years.

The control group (Group II) consisted of 60 workers employed in different services and industries in Veles, other than lead industry, without any occupational exposure to lead (living in urban areas where leaded petroleum can still be found and having lead-emitting industrial facilities in the local environment); 50 were men and 10 women, aged $(42.2 \pm 8.7)$ years, with total employment duration of $(18.9 \pm 9.7)$ years.

The two groups did not significantly differ in demographic characteristics, environmental exposure, total duration of employment, smoking habit, and alcohol consumption. The study included only those subjects who had complete data from all examinations and tests. All 120 qualifying subjects volunteered for the research and gave their oral consent. The study was approved by the bioethical committee and performed according to the Declaration of Helsinki. The basic criteria for determining occupational risk factors in the study were data collected by the questionnaire for lead exposure and toxic effect assessment.

\section{Clinical examinations}

Physical examination of each subjects included the eyes (redness, pruritus, tearing, discharge, and photophobia), nose (sneezing, nasal itching, rhinorrhoea, and nasal blockage), lungs (wheezing, breathlessness, chest tightness, coughing and phlegm), and skin (rash, pruritus and inflammation). It was followed by spirometry using the Ganshorn SanoScope LF8 (Ganshorn Medizin Electronic GmbH, Germany) which included measurement of the forced vital capacity (FVC), forced expiratory volume in one second $\left(\mathrm{FEV}_{1}\right), \mathrm{FEV}_{1} / \mathrm{FVC}$ ratio, maximal expiratory flow at $50 \%, 25 \%$, and $25 \%$ to $75 \%$ of FVC $\left(\mathrm{MEF}_{50}\right.$, $\mathrm{MEF}_{25}$, and $\mathrm{MEF}_{25-75}$, respectively), in all subjects. The results are expressed as percentages of the predicted values set by the European Community for Coal and Steel (ECCS) norms (23). Finally, all subjects underwent ECG testing at steady state.

\section{Laboratory testing}

Blood lead level was determined in the Republic Institute for Health Protection, Skopje using a PERKIN ELMER 4100 HGA 700 atomic absorption spectrometer (AAS) with an auto-sampler AS-70. Venous blood (about $2 \mathrm{~mL}$ ) was taken into a sterile vacutainer with $\mathrm{K}_{2}$ EDTA $1.5 \mathrm{mg} \mathrm{mL}^{-1}$ of blood and transported in a portable refrigerator at $+4{ }^{\circ} \mathrm{C}$ on the same day. Lead was extracted into a mixture of $\mathrm{HNO}_{3}$ and $\mathrm{HCl}$ under pressure using a microwave furnace PAAR PHYSICA-PERKIN ELMER designed for laboratory use $(24,25)$. The sensitivity of the method is $4.4 \times 10^{-10} \mathrm{~g} \mathrm{~Pb}(26,27)$. Biological material (venous blood and urine spot samples) was taken to determine the biomarkers of lead effect at the Institute of Occupational Health, Skopje.

ALAD activity was determined in $0.2 \mathrm{~mL}$ venous blood samples with heparin using the spectrophotometric method within 24 hours of sampling because of ALAD's instability. An ALA substrate was added to the haemolised blood to facilitate a reaction between ALAD and its substrate ALA, which resulted in the forming of porphobilinogen. The amount of porphobilinogen, determined by spectrophotometry at $555 \mathrm{~nm}$ after adding $p$-dimethyl amino benzaldehid, showed the $\operatorname{ALAD}$ activity $(28,29)$. ALA concentration in the urine was determined by condensing $1 \mathrm{~mL}$ spot urine samples with acetyl acetone into a pyrole compound which together with para-dimethy-aminobenzaldehyd gave a red coloured complex that was determined by spectrophotometric method at $553 \mathrm{~nm}$ (30). Coproporphyrin concentration in urine spot samples was determined by spectrophotometric absorption 
measurement at $401 \mathrm{~nm}$ of the urine extract by ether and afterwards by $\mathrm{HCl}$ (29). Reticulocyte count was determined in blood sample (31), and count of erythrocytes with basophilic stipplings (EBS) was carried out using two mixtures: $2 \mathrm{~g}$ boric acid $+1 \mathrm{~g}$ methylen blue and $0.28 \mathrm{~g} \mathrm{NaOH}$ in $100 \mathrm{~mL}$ of distilled water. This mixture was used to paint the blood sample on the microscopic glass and then fix it and analyse by microscope (32). Blood haemoglobin concentration was determined using the colourimetric method (33), while erythrocytes and leukocytes were counted using the haematological counter (34).

\section{Statistical analysis}

Data were analysed with descriptive and inferential statistical methods using STATISTICA for Windows release 7 and Epi Info 6. A data base was created using specific computer applications for this purpose (Delphi 5, MS Excel). Descriptive statistical analysis included tables and figures containing statistical

Table 1 Characteristics of the study subjects series according to the defined variables. Continuous variables were expressed as mean values with standard deviation (SD) and nominal variables as numbers and percentages. The chi-square test (or Fisher's exact test where appropriate) was used for testing differences in frequency. A P-value below 0.05 was considered statistically significant. Risk was assessed using the odds ratio (OR) with $95 \%$ confidence interval $(\mathrm{CI})$.

\section{RESULTS}

Table 1 shows the subject demographics. The prevalence of non-work-related symptoms in the previous 12 months was not significantly higher in lead workers than in controls, except for the muscle pain and droopiness (Table 2).

Table 3 shows the prevalence of work-related symptoms in both groups over the last 12 months. Work-related worsening of the symptoms of the

\begin{tabular}{lcc}
\hline Variable & Lead workers $(\mathbf{n}=60)$ & Controls $(\mathbf{n}=60)$ \\
\hline Sex / men/women ratio & 5.6 & 5.0 \\
Age $/$ years & $45.1 \pm 7.6$ & $42.2 \pm 8.7$ \\
BMI / kg m ${ }^{-2}$ & $25.3 \pm 3.4$ & $26.4 \pm 3.6$ \\
Years of employment & $23.1 \pm 7.2$ & $18.9 \pm 9.7$ \\
Years of exposure & $18.8 \pm 7.5$ & $/$ \\
Daily smokers & $25(41.6 \%)$ & $26(43.3 \%)$ \\
Years of smoking & Range $=0$ to $40 ;$ median $=8.5$ & Range $=0$ to $42 ;$ median $=10.5$ \\
Cigarettes per day & Range $=0$ to $35 ;$ median $=7.3$ & Range $=0$ to $40 ;$ median $=8.2$ \\
Ex-smokers & $7(11.6 \%)$ & $9(15.0 \%)$ \\
Passive smokers & $8(13.3 \%)$ & $7(11.7 \%)$ \\
\hline
\end{tabular}

Numerical data are expressed as means with standard deviations; the frequencies of active smoking, ex-smoking, and passive smoking are expressed as absolute numbers and percentages of subjects.

BMI: body mass index.

Table 2 History of non-work-related symptoms in 60 lead workers and 60 control subjects in the last 12 months

\begin{tabular}{lccc}
\hline Symptoms & Lead workers $(\mathbf{n}=60)$ & Controls $(\mathbf{n}=60)$ & P-value * \\
\hline Headache & $17(26.6 \%)$ & $13(21.6 \%)$ & 0.513 \\
Insomnia & $7(11.6 \%)$ & $5(8.3 \%)$ & 0.582 \\
Low appetite & $8(13.3 \%)$ & $4(6.6 \%)$ & 0.271 \\
Muscle pain & $20(33.3 \%)$ & $8(13.3 \%)$ & 0.041 \\
Decreased body weight & $2(3.3 \%)$ & 0 & 0.161 \\
Droopiness & $22(36.6 \%)$ & $7(11.6 \%)$ & 0.012 \\
Gastrointestinal symptoms & $15(25 \%)$ & $9(15 \%)$ & 0.263 \\
Grumpiness & $8(13.3 \%)$ & $2(3.3 \%)$ & 0.068 \\
\hline
\end{tabular}

Data are expressed as number and percentage of subjects with certain variable.

* Tested by the chi-square test. 
eyes, nose, lungs, and skin) was reported by $18.3 \%$, $28.3 \%, 20 \%$, and $10 \%$ of lead workers, respectively and by $6.6 \%, 10 \%, 6.6 \%$, and $6.6 \%$ controls, respectively. A significant difference between lead workers and controls was only found for work-related nasal symptoms $(P=0.035)$. The prevalence of lung symptoms was higher in lead workers than in controls, but the difference was not significant $(20 \%$ vs. $6.6 \%$ ).

Table 4 shows the reference values for biological markers of lead exposure and effect. Table 5 shows the mean values for biological markers of exposure and effect. BLL and ALA were significantly higher, and ALAD activity significantly lower in lead workers than in controls. Lead workers also had a higher rate of abnormal BLL, ALAD, and ALA, but the difference was significant only for BLL and ALAD (Table 6). The percentage of abnormal coproporphyrine, haemoglobin, reticulocytes, EBS, and erythrocyte count was equal or lower than in controls (Table 6). This is due to the fact that BLL mainly reflects current lead exposure, ALAD better reflects long-

Table 3 Prevalence of work-related symptoms in 60 lead workers and 60 control subjects within the last 12 months

\begin{tabular}{lccc}
\hline Symptoms of & Lead workers $(\mathbf{n}=60)$ & Controls $(\mathbf{n}=60)$ & P-value * \\
\hline Eyes & $11(18.3 \%)$ & $4(6.6 \%)$ & 0.088 \\
Nose & $17(28.3 \%)$ & $6(10 \%)$ & 0.035 \\
Lungs & $12(20.0 \%)$ & $4(6.6 \%)$ & 0.059 \\
Skin & $6(10.0 \%)$ & $4(6.6 \%)$ & 0.543 \\
\hline
\end{tabular}

Data are expressed as number and percentage of subjects with certain variable.

* Tested by the chi-square test.

Table 4 Biological markers and reference values

\begin{tabular}{lc}
\hline Biological markers & Reference values \\
\hline BLL & $<100 \mu \mathrm{g} \mathrm{L}^{-1}$ \\
Erythrocytes count & $\left(3.8 \times 10^{12}\right.$ to $\left.5.8 \times 10^{12}\right) \mathrm{L}^{-1}$ \\
Hemoglobin concentration & $(110$ to 180$) \mathrm{g} \mathrm{L}^{-1}$ \\
Reticulocytes count & $(5$ to 25$) \%$ o \\
ALAD & $(1336$ to 2000$) \mathrm{ncat}$ \\
EBS count & 0 to 100 \\
ALA & $76 \mu \mathrm{mol} \mathrm{L}^{-1}$ \\
Coproporphyrine & $0.18 \mu \mathrm{mol} \mathrm{L}^{-1}$ \\
\hline
\end{tabular}

Data are expressed as certain variable with referent values.

Table 5 Findings of biological markers in 60 lead workers and 60 control subjects

\begin{tabular}{|c|c|c|c|}
\hline Biomarkers & $\begin{array}{c}\text { Lead workers } \\
(n=60) \\
\text { Mean } \pm \text { SD (range) }\end{array}$ & $\begin{array}{c}\text { Controls } \\
(n=60) \\
\text { Mean } \pm \text { SD (range) }\end{array}$ & P-value * \\
\hline $\mathrm{BLL} / \mu \mathrm{g} \mathrm{L}^{-1}$ & $164 \pm 85(33-467)$ & $70 \pm 54(0-277)$ & 0.000 \\
\hline Erythrocytes / x10 $12 \mathrm{~L}^{-1}$ & $4.9 \pm 0.5(3.2-6.2)$ & $4.8 \pm 0.4(3.7-5.7)$ & 1.000 \\
\hline Hemoglobin /g L-1 & $149 \pm 10.6(119-166)$ & $149.6 \pm 12.1(118-178)$ & 0.948 \\
\hline Reticulocytes / \%。 & $15.1 \pm 3.5(8-25)$ & $14.9 \pm 5.7(9-50)$ & 0.848 \\
\hline ALAD / ncat & $1238.1 \pm 647.4(82-3990)$ & $2096.5 \pm 910.8(233-4036)$ & 0.000 \\
\hline EBS count & $30.8 \pm 54.5(0-350)$ & $26.8 \pm 37.2(0-150)$ & 0.639 \\
\hline $\mathrm{ALA} / \mu \mathrm{mol} \mathrm{L}^{-1}$ & $45.1 \pm 32.2(13.7-221.5)$ & $28.1 \pm 17.8(2.3-86.9)$ & 0.0005 \\
\hline Coproporphyrine / $\mu \mathrm{mol} \mathrm{L}^{-1}$ & $0.06 \pm 0.04(0.01-0.3)$ & $0.06 \pm 0.04(0.006-0.24)$ & 0.681 \\
\hline
\end{tabular}

*Compared by independent-samples t-test. 
term, cumulative lead exposure level, whereas ALA, coproporphyrine, and EBS are not specific enough, and erythrocyte count, reticulocyte count, and haemoglobin concentration are not specific at all for lead exposure. Correlations between the examined parameters and BLL, ALAD and ALA in lead workers are shown in Table 7. Inverse correlation was found between BLL and ALAD ( $r=-0.546, P<0.01)$, and positive correlation BLL between and age $(\mathrm{r}=0.331$, $P<0.01)$, years of employment $(\mathrm{r}=0.418, P<0.01)$, and years of exposure $(\mathrm{r}=0.419, P<0.01)$. Inverse correlation was found between ALAD and age $(\mathrm{r}=-$ $0.256, P<0.05)$, years of employment $(\mathrm{r}=-0.371$, $P<0.01)$, and years of exposure $(\mathrm{r}=-0.343, P<0.01)$. ALAD also inversely correlated with systolic blood pressure $(\mathrm{r}=-0.262, P<0.05)$, alcohol consumption $(\mathrm{r}=-0.277, P<0.05)$, and years of alcohol consumption $(\mathrm{r}=-0.301, P<0.05)$. Body mass index, smoking, ECG abnormality, number of cigarettes per day and years of smoking did not correlate with either BLL or ALAD. Changes in spirometric parameters correlated inversely with BLL $(\mathrm{r}=-0.255, P<0.05)$. As far as standard

Table 6 Prevalence of deviation in biological markers in 60 lead workers and 60 control subjects

\begin{tabular}{lccc}
\hline Biomarkers & $\begin{array}{c}\text { Lead workers } \\
(\mathbf{n}=60)\end{array}$ & $\begin{array}{c}\text { Controls } \\
(\mathbf{n}=60)\end{array}$ & P-value * \\
\hline BLL & $46(76.7 \%)$ & $11(18.3 \%)$ & 0.0001 \\
Erythrocytes & $1(1.7 \%)$ & $1(1.7 \%)$ & 1.00 \\
Haemoglobin & 0 & $1(0.02 \%)$ & 0.319 \\
Reticulocytes & $8(13.3 \%)$ & $8(13.3 \%)$ & 1.00 \\
ALAD & $40(66.7 \%)$ & $13(21.7 \%)$ & 0.0018 \\
EBS & $6(10.0 \%)$ & $7(11.7 \%)$ & 0.792 \\
ALA & $5(8.3 \%)$ & $1(1.7 \%)$ & 0.110 \\
Coproporphyrine & $1(1.7 \%)$ & $2(3.3 \%)$ & 0.568 \\
\hline
\end{tabular}

Data are expressed as number and percentage of subjects with certain variable.

* Tested by chi-square test.

Table 7 Spearman's rank correlation coefficients for relationship between the examined parameters and blood lead level (BLL), $\delta$-aminolevulinic acid dehydratase (ALAD), $\delta$-aminolevulinic acid (ALA)

\begin{tabular}{lccc}
\hline Parameters & BLL & ALAD & ALA \\
\hline BLL & 1 & $-0.546^{* *}$ & -0.005 \\
ALAD & $-0.546^{* *}$ & 1 & -0.071 \\
ALA & -0.005 & -0.071 & 1 \\
Age & $0.331^{* *}$ & $-0.256^{* *}$ & -0.022 \\
Years of employment & $0.418^{* *}$ & $-0.371^{* *}$ & 0.026 \\
Years of exposure & $0.419^{* *}$ & $-0.343^{* *}$ & 0.115 \\
Body mass index & $-0,078$ & $-0,064$ & 0,038 \\
Blood pressure & 0.129 & $-0.262^{*}$ & -0.029 \\
Smoking habit & -0.002 & -0.065 & 0.052 \\
Years of smoking & 0.096 & -0.158 & -0.130 \\
Cigarettes per day & 0.034 & -0.066 & 0.027 \\
Alcohol consumption & 0.179 & $-0.277^{*}$ & 0.082 \\
Years of alcohol consumption & 0.177 & $-0.301^{*}$ & 0.107 \\
Spirometric changes & $-0.255^{*}$ & 0.078 & -0.018 \\
ECG abnormalities & 0.106 & -0.179 & -0.012 \\
Erythrocyte count & $0.258^{*}$ & -0.137 & -0.151 \\
Haemoglobin & $0.261^{*}$ & $-0.322^{*}$ & 0.072 \\
Haematocrit & 0,157 & 0.209 & -0.302 \\
Leukocyte count & 0.017 & -0.118 & -0.111 \\
\hline
\end{tabular}

Level of statistical significance: ${ }^{*} P<0.05 ; * * P<0.01$ 
haematological findings are concerned, a positive correlation was found between BLL and erythrocyte count $(\mathrm{r}=0.258, P<0.05)$ and BLL and haemoglobin $(\mathrm{r}=0.261, P<0.05)$, and inverse correlation was found between ALAD and haemoglobin $(r=-0.322, P<0.05)$. No correlation was found between BLL or ALAD and leukocyte count and haematocrit, or between BLL and systolic blood pressure. Biomarker risks were evaluated in lead workers and controls using the odds ratio (OR) with $95 \%$ confidence interval (CI). A significant difference was found for BLL and ALAD, with very high odds ratios (14.64 and 7.23 respectively), as well as high relative risk (RR) (4.18 and 3.08 respectively) (Table 8 ).

\section{DISCUSSION}

The average blood lead in lead workers $(164 \mu \mathrm{g}$ $\left.\mathrm{L}^{-1}\right)$ was significantly $(P=0.000)$ higher than in control subjects $\left(70 \mu \mathrm{g} \mathrm{L}^{-1}\right)$ (Table 5). General population in Macedonia seems to have a higher blood lead level than in other industrially developed countries such as Sweden $\left(25 \mu \mathrm{g} \mathrm{L}^{-1}\right)(35)$, USA $\left(27 \mu \mathrm{g} \mathrm{L}^{-1}\right)$, Thailand (32 $\left.\mu \mathrm{g} \mathrm{L}^{-1}\right)$ (36), Poland $\left(27 \mu \mathrm{g} \mathrm{L}^{-1}\right)$ (37), Germany $\left(36 \mu \mathrm{g} \mathrm{L}^{-1}\right)$ (38) or Italy $\left(45 \mu \mathrm{g} \mathrm{L}^{-1}\right)$ (39), perhaps because leaded gasoline is still widely used in Macedonia. Values of BLL and ALAD also depend on genotype variants (4). Of eight ALAD gene variants, we focused on one polymorphism that yields two alleles, designated ALAD-1 and ALAD-2, which exhibit a codominant pattern of inheritance (40). Ziemsen et al. (41) found that lead-exposed workers with the ALAD 1-2 genotype had higher blood lead levels than ALAD 1-1 homozygotes ( $440 \mu \mathrm{g} \mathrm{L}^{-1}$ vs. $380 \mu \mathrm{g} \mathrm{L}^{-1}$ ) and that
ALAD 2-2 homozygotes had still higher blood lead levels $\left(560 \mu \mathrm{g} \mathrm{L}^{-1}\right)$. Hypotheses based on the charge of the ALAD-2 isozyme (42) imply that the ALAD 1-2 and 2-2 genotypes are the "at-risk genotypes" at high exposure levels. The average value of ALAD (1238.1 ncat) in lead workers was significantly $(P=0.000)$ lower than in controls (2096.5 ncat) (Table 5). ALAD has a highly significant correlation with BLL at very low BLL, and is also sensitive to high lead (43). The comparative advantage of ALAD with respect to other biological markers of effect seems to be its relatively higher specificity for increased lead absorption. ALAD may be inhibited by alcohol and smoking (44). However, Telišman et al. (45) found that transient inhibition of ALAD by alcohol is owed to ethanol per se, but mainly to an ethanol-induced increase in the biologically active fraction of lead accumulated in the organism. Namely, alcohol can affect the lead distribution in the body and increase urinary excretion of lead because of a transient increase in tissue redox potential resulting from ethanol metabolism $(45,46)$. Our data showed no correlation between ALAD and smoking habit, years of smoking, and the number of cigarettes per day, but there was an inverse correlation between ALAD and alcohol consumption $(\mathrm{r}=-0.277, P<0.05)$ and ALAD and years of alcohol consumption $(\mathrm{r}=-0.301, P<0.05)$. A strong positive correlation was found between BLL and years of employment $(\mathrm{r}=0.418, P<0.01)$ as well as between BLL and years of exposure $(\mathrm{r}=0.419, P<0.01)$, while the correlation between these variables and ALAD was inverse $(\mathrm{r}=-0.371, P<0.01$ and $\mathrm{r}=-0.343, P<0.01$, respectively). As the main parameter of airway obstruction, $\mathrm{FEV}_{1}$ is used to determine the degree of lung function impairment (47). Our results showed an

Table 8 Biomarker risk evaluation using the odds ratio (OR) with $95 \%$ confidence interval (CI) in lead workers and controls

\begin{tabular}{lccc}
\hline Biomarkers & Odds ratio & Relative risk $(\mathrm{CI}=95 \%)$ & P-value * \\
\hline BLL & $14.64(5.57<\mathrm{OR}<39.60)$ & $4.18(2.41<\mathrm{RR}<7.26)$ & 0.0000 \\
Erythrocytes & $1.0(0.0<\mathrm{OR}<37.61)$ & $1.0(0.06<\mathrm{RR}<15.62)$ & 1.000 \\
Haemoglobin & $0.0(0.0<\mathrm{OR}<17.54)$ & $/$ & 0.315 \\
Reticulocytes & $1.0(0.31<\mathrm{OR}<3.21)$ & $1.0(0.4<\mathrm{RR}<2.49)$ & 0.558 \\
ALAD & $7.23(2.98<\mathrm{OR}<17.87)$ & $3.08(1.84<\mathrm{RR}<5.14)$ & 0.0000007 \\
EBS & $0.84(0.23<\mathrm{OR}<3.03)$ & $0.86(031<\mathrm{RR}<2.40)$ & 0.768 \\
ALA & $5.36(0.58<\mathrm{OR}<125.23)^{* *}$ & $5.0(0.60<\mathrm{RR}<41.53)^{* *}$ & 0.0938 \\
Coproporphyrine & $0.49(0.02<\mathrm{OR}<7.19)$ & $0.50(0.05<\mathrm{RR}<5.37)$ & 0.558 \\
\hline
\end{tabular}

* Tested by the chi-square test

** Cornfield not accurate 
inverse correlation between $\mathrm{FEV}_{1}$ and $\mathrm{BLL}(\mathrm{r}=-0.255$, $P<0.05)$, but we have not taken into account of the effect of smoking on $\mathrm{FEV}_{1}$ and $\mathrm{FEV}_{1} / \mathrm{BLL}$ ratio. Some studies confirmed the effect of exposure duration on the prevalence of respiratory symptoms (48). Anaemia observed in lead-exposed individuals is of the hypochromic and normocytic (also microcytic) type, and is accompanied by reticulocytosis with basophilic stippling. Reduced haem synthesis is seen at blood lead levels of $500 \mu \mathrm{g} \mathrm{L}^{-1}$ (49). Our data showed a positive correlation between haemoglobin concentration and BLL ( $\mathrm{r}=0.261, P<0.05)$, and inverse correlation between haemoglobin and ALAD $(r=-0.322, P<0.05)$, which is in agreement with the findings of Kelada et al. (4). No such correlation was seen for haematocrit and leukocyte count in exposed workers, although some authors reported immune response in longterm lead exposure (50). A positive correlation was found between BLL and age $(\mathrm{r}=0.331, P<0.01)$, and inverse between ALAD and age $(\mathrm{r}=-0.256, P<0.05)$, which corresponds to some earlier studies $(35,39)$. Body mass index showed no correlation with biological markers of lead exposure and effect. Lead exposure is also weakly associated with increased blood pressure and hypertension in general and occupationally exposed population. Pocock et al. (51) concluded that increased hypertension [systolic pressure greater than $160 \mathrm{~mm} \mathrm{Hg}(21.33 \mathrm{kPa})$, diastolic pressure greater than $100 \mathrm{~mm} \mathrm{Hg}(13.33 \mathrm{kPa})]$ was associated with blood lead concentrations greater than $370 \mu \mathrm{g} \mathrm{L}^{-1}$. Morris et al. (52) reported that BLL of $100 \mu \mathrm{g} \mathrm{L}^{-1}$ produced a systolic increase of $5 \mathrm{~mm} \mathrm{Hg}(0.66 \mathrm{kPa})$ in men. Our findings showed an inverse correlation between systolic blood pressure and ALAD $(r=-0.262$, $P<0.05)$, and no correlation with BLL. A significant difference was found for BLL and ALAD between lead workers and controls, with very high odds ratios (14.64 and 7.23 , respectively) and high relative risk (4.18 and 3.08 , respectively). By identifying the proteins prone to bind lead, we may be able to understand lead toxicity better, find markers of lead exposure and effects, and identify susceptible individuals (53).

\section{CONCLUSION}

This study of lead exposure has provided some data for risk assessment, such as in the rate of abnormalities in specific biomarkers of lead effect in individuals in lead production and refining versus unexposed controls. It also examined the relationship between occupational exposure and lead toxicity, focusing on haematopoiesis. Our data confirmed the association between occupational lead exposure and abnormalities in specific biological markers of lead effect and the role of occupational exposure in the development of adverse effects. We also investigated the possible influence of smoking, alcohol consumption, and lead air pollution caused by car exhaust (since lead is still used as a petrol additive) and melting plant emissions. Our data corroborate the need to devise preventive measures and activities for exposed individuals, and to improve regulation of occupational and environmental exposure. As genetic polymorphism of ALAD has been confirmed to modify lead toxicity, identification of susceptible individuals and population groups should be integrated in regulatory and specific protective public health solutions.

\section{REFERENCES}

1. Eisinger J. Sweet poison. Episodic outbreaks of colic, or 'wine disease,' plagued Europe for many centuries, even after an obscure German physician traced the cause to lead. Nat Hist 1996;105:48-53.

2. Needleman LH. History of lead poisoning in the world. [displayed 10 November 2007]. Available at http://www. leadpoison.net/general.htm.

3. Kocubovski M. Dejstvoto na olovoto od ambientniot vozduh i evaluacija na zdravstvenata sostojba kaj učilisna populacija [Influence of lead from ambient air and evaluation of health condition in school children, in Macedonian]. [PhD Thesis]. Skopje: Medical faculty, University "Sts. Cyril and Methodius" Skopje; 2004.

4. Kelada NS, Shelton E, Kaufmann RB, Khoury JM. $\delta$-Aminolevulinic acid dehydratase genotype and lead toxicity: a HuGE review. Am J Epidemiol 2001;154:113.

5. Orusev T. Occupational Medicine. Skopje: Medical Faculty, University "Sts Cyril and Methodius" Skopje; 1982.

6. Isjanovska R. Epidemiološko proučuvanje na toksičnite efekti na olovoto i negovite sodinenija pri profesionalna ekspozicija [Epidemiologic research of the toxic effects of lead and its compounds in the terms of occupational exposure, in Macedonian]. [PhD thesis]. Skopje: Medical Faculty, University "Sts. Cyril and Methodius" Skopje; 1999.

7. Vidaković A. Lead. In: Vidaković A, editor. Occupational toxicology. Belgrade: Society of Toxicologists of Yugoslavia; 2000. p. 316-29. 
8. Hernandez-Avila M, Cortez-Lugo M, Munoz I, Tellez MM, Rojo S. Lead exposure in developing countries. Studies and findings 1999 [displayed 10 November 2007]. Available at http://www.leadpoison.net/general. htm.

9. Needleman LH. Clamped in a straitjacket: The insertion of lead into gasoline. Environ Res 1997;74:95-103.

10. U.S. Environmental Protection Agency (EPA). Air Quality Criteria for Lead. Washington (DC): EPA; 1986.

11. U.S. Environmental Protection Agency (EPA). Lead effects on cardiovascular function, early development, and stature: an addendum to EPA Air Quality Criteria for Lead (1986). In: Air Quality Criteria for Lead. Washington (DC): EPA; 1986.

12. U.S. Environmental Protection Agency (EPA). Evaluation of the potential carcinogenicity of lead and lead compounds. Washington (DC): EPA; 1989.

13. Agency for Toxic Substances and Disease Registry (ATSDR). Toxicological Profile for Lead. Update. Prepared by Clement International Corporation under contract No. 205-88-0608 for ATSDR. Atlanta (GA): U.S. Public Health Service; 1993.

14. Sussel A, editor. Protecting workers exposed to leadbased paint hazards: a report to Congress. Washington (DC): U.S. Department of Health and Human Services; 1987. [displayed 10 November 2007]. Available at http://www.cdc.gov/Niosh/98-112.html.

15. Sakai T. Biomarkers of lead exposure. Industrial Health 2000;38:127-42.

16. Mahaffey K, McKinney J, Reigart JR. Lead and compounds. In: Lippmann M, editor. Environmental toxicants, human exposures and their health effects. $2^{\text {nd }}$ ed. New York (NY): John Wiley and Sons, Inc.; 2000. p. 481-521.

17. McElvaine MD, Orbach HG, Binder S, Blanksma LA, Maes EF, Krieg RM. Evaluation of the erythrocyte protoporphyrin test as a screen for elevated blood lead levels. J Pediatr 1991;119:548-50.

18. Agency for Toxic Substances and Disease Registry (ATSDR). Public health statement for lead. Atlanta, GA: U.S. Department of Health and Human Services, Public Health Service, Agency for Toxic Substances and Disease Registry; 1997.

19. U.S. Food and Drug Agency (FDA). Provisional Tolerable Exposure Levels for Lead (Memorandum). Rockville (MD): US Public Health Service, Contaminants Team HFF-156; 1990.

20. Kappas A, Sassa S, Galbraith RA. The porphyrias. In: Scriver CR, Beaudet AL, Sly WS, editors. The metabolic and molecular basis of inherited disease. $7^{\text {th }}$ ed. New York (NY): McGraw-Hill Book Company; 1995. p. 2103 59.

21. Jaffe EK, Bagla S, Michini PA. Reevaluation of a sensitive indicator of early lead exposure: measurement of porphobilinogen synthase in blood. Biol Trace Elem Res 1991;28:223-31.
22. Stoleski S, Karadžinska-Bislimovska J, Mijakoski D, Ristova V, Risteska-Kuc S, Matevski T, Stikova E. Risk assessment and modern approach to lead intoxication. In: Proceedings of the $3^{\text {rd }}$ Congress of Preventive Medicine in R. Macedonia with International Participation; 4-7 Oct 2006; Ohrid, R. Macedonia. Skopje: Macedonian Medical Association; 2006. p. 189.

23. Quajner $\mathrm{PhH}$, editor. Standardization of lung function tests - 1993 update. Report Working Party for the European Community for Steel and Coal. Official Statement of the European Rrespiratory Society. Eur Rrespir J 1993;16(Suppl):1-100.

24. Prpić-Majić D. Toksikološko-kemijske analize [Toxicological and chemical analyes, in Croatian]. Beograd-Zagreb: Medicinska knjiga; 1985. p. 32-8.

25. Miller DT, Paschal DC, Gunter EW, Stroud PE, D’Angelo J. Determination of lead in blood using electrothermal atomization atomic absorption spectrometry with a L'vov platform and matrix modifier. Analyst 1987;112:17014.

26. Voelkopf V, Grobenski Z, Schlemmer G, Weiz B. Determination of lead in blood - Graphite furnace method atomic absorption spectroscopy. Methods of sampling and analysis MTA/MB-011/R92 2007 [displayed 12 November 2007]. Available at http://www. mtas.es/INSHT/en/MTA/MB_011_R92_en.htm.

27. U.S. Environmental Protection Agency (US EPA). Reference method for the determination of lead in suspended particulate matter collected from ambient air. Cincinnati: Center for Environmental Research Information; 1994.

28. Bonsignore D, Calissano P, Cartasangna C. Un semplice metodo per la determinazione della deltaaminolevulinico-deidratasi nel sangue [A simple method to determine blood delta-aminolevulinic acid dehydratase, in Italian]. Med Lav 1965;56:199.

29. Cvetanov V, Stikova E, Karadžinska-Bislimovska J. Health condition and work ability. Skopje: Institute of Occupational Health; 1989.

30. Grabecki J, Haduch T, Urbanowicz H. Die einfachen Bestimmungsmethoden der $\delta$-Aminolavulinsaure im Harn [Simple regulation methods of the aminolevulinic acid in the urine, in German]. Int Arch Gewerbepathol Gewerbehyg 1967;23:226.

31. England JM, Rowan RM, Van Assendelft OW, Bull BS, Coulter WH, Fujimoto K, Groner W, Van Hove I, Jones AR, Kanter RJ, Klee GG, Koepke JA, Lewis SM, D'Onofrio G, Tatsumi N. Proposed reference method for reticulocyte counting based on the determination of the reticulocyte to red cell ratio. The Expert Panel on Cytometry of the International Council for Standardization in Haematology. Clin Lab Haematol 1998;20:77-9.

32. Tasevski S, Velkov S, Kostoski D. Determination of basophil punctuated erythrocytes count as a diagnostic 
method for occupational saturnism. Laboratory 2002;4:13-6.

33. Frank RS, Wyatt JL. Method and apparatus for determination of hemoglobin content of individual red blood cells 1997 [displayed 12 November 2007]. Available at http://www.freepatentsonline. com/5686309.html.

34. Ost V, Neukammer J, Rinneberg H. Flow cytometric differentiation of erythrocytes and leukocytes in dilute whole blood by light scattering. Cytometry 1998;32:191-7.

35. Bárány E, Bergdahl IA, Bratteby LE, Lundh T, Samuelson G, Schütz A, Skerfving S, Oskarsson A. Trace elements in blood and serum of Swedish adolescents: relation to gender, age, residential area, and socioeconomic status. Environ Res 2002;89:7284.

36. Sirivarasi J, Kaorjaren S, Wananukul W, Srisomerg P. Non-occupational determinants of cadmium and lead in blood and urine among a general population in Thailand. Southeast Asian J Trop Med Public Health 2002;33:180-7.

37. Szymik E. The fate of children from Piekary Slaskie with elevated lead concentration in blood. Wiad Lek 2002;55:72-80.

38. Becker K, Kaus S, Krause C, Lepom P, Schulz C, Seiwert M, Seifert B. German Environmental Survey 1998 (GerEs III): environmental pollutants in blood of the German population. Int J Hyg Environ Health 2002;205:297-308.

39. Apostoli P, Baj A, Bavazzano P, Ganzi A, Neri G, Ronchi A, Soleo L, Di LL, Spinelli P, Valente T, Minoia C. Blood lead reference values: the results of an Italian polycentric study. Sci Total Environ 2002;287:1-11.

40. Battistuzzi G, Petrucci R, Silvagni L, Urbani FR, Caiola S. $\delta$-Aminolevulinate dehydrase: a new genetic polymorphism in man. Ann Hum Genet 1981;45:2239.

41. Ziemsen B, Angerer J, Lehnert G, Benkmann HG, Goedde HW. Polymorphism of $\delta$-aminolevulinic acid dehydratase in lead-exposed workers. Int Arch Occup Environ Health 1986;58:245-7.
42. Wetmur JG. Influence of the common human $\delta$ aminolevulinate dehydratase polymorphism on lead body burden. Environ Health Perspect 1994;102(Suppl 3):215-9.

43. Telišman S, Keršanc A, Prpić-Majić D. The relevance of arguments for excluding ALAD from the recommended biological limit values in occupational exposure to inorganic lead (WHO 1980). Int Arch Occup Environ Health 1982;50:397-412.

44. Doss M, Laubenthal F, Stoeppler M. Lead poisoning in inherited $\delta$-aminolevulinic acid dehydratase deficiency. Int Arch Occup Environ Health 1984;54:55-63.

45. Telišman S, Prpić-Majić D, Kežić S. In vivo study on lead and alcohol interaction and the inhibition of erythrocyte delta-aminolevulinic acid dehydratase in man. Scand J Work Environ Health 1984; 10:239-44.

46. Newton D, Pickford CJ, Chamberlain AC, Sherlock JC, Hislop JS. Elevation of lead in human blood from its controlled ingestion in beer. Hum Exp Toxicol 1992;11:3-9.

47. Žuškin E. Lung function tests. In: Gamulin S, Marušič M, Krvavica S, editors. Pathophysiology. Third edition. Zagreb: Medicinska naklada; 1995. p. 656-9.

48. Rastogi SK, Gupta BN, Husain T, Mathur N, Srivastava S. Spirometric abnormalities among welders. Environ Res 1991;56:15-24.

49. Goyer RA. Toxic effects of metals. In: Klaassen CD, editor. Casarett and Doull's toxicology: the basic science of poisons. $5^{\text {th }}$ ed. New York (NY): McGraw-Hill Book Company; 1996. p. 691-736.

50. Kuo HW, Hsiao TY, Lai JS. Immunological effects of long-term lead exposure among Taiwanese workers. Arch Toxicol 2001;75:569-73.

51. Pocock SJ, Shaper AG, Ashby DT, Whitehead TP. Blood lead concentration, blood pressure, and renal function. Br Med J1984;289:872-4.

52. Morris C, McCarron DA, Benett WM. Low-level lead exposure blood pressure, and calcium metabolism. Am J Kidney Dis 1990;15:568-74.

53. Bergdahl IA. Lead-binding proteins - a way to understand lead toxicity? Analusis Magazine 1998;26: M81-5. 


\section{Sažetak}

\section{ŠTETNI UČINCI ANORGANSKOG OLOVA U METALURŠKIH RADNIKA}

Napravljeno je retrospektivno ispitivanje koje je obuhvatilo 60 radnika profesionalno izloženih anorganskomu olovu te skupinu od 60 kontrolnih ispitanika. Ispitivanje se temeljilo na posebnome upitniku o izloženosti olovu i procjeni toksičnoga djelovanja, liječničkome pregledu, spirometriji, EKG-u te laboratorijskim pretragama za olovo u krvi i toksične učinke olova. Statistički značajno zastupljeniji simptomi zamijećeni u izloženih radnika bili su bol u mišićima i klonulost te teškoće s disanjem na nos povezane s poslom. Zastupljenost plućnih teškoća bila je nešto viša u radnika izloženih olovu, ali ne značajno (20\% naprema 6,6 \%). Srednje razine olova i delta-aminolevulinske kiseline (d-ALA) u krvi bile su značajno više u izloženih radnika. Usto je i aktivnost enzima dehidrataze d-ALA (ALAD) bila značajno niža negoli u kontrolnih ispitanika. Učestaliji abnormalni nalazi olova, ALAD-a i d-ALA zamijećeni su u krvi radnika izloženih olovu, a statistička je značajnost zabilježena za olovo i ALAD. Inverzna je korelacija utvrđena između olova i ALAD-a u krvi, a pozitivna korelacija između olova u krvi i dobi, godina zaposlenja, godina izloženosti, krvnoga tlaka, konzumacije alkohola i godina konzumacije alkohola. Promjene u spirometrijskim parametrima inverzno su korelirale s olovom u krvi. Pozitivno su korelirali olovo u krvi i broj eritrocita te koncentracija hemoglobina, a inverzno ALAD i koncentracija hemoglobina. Značajne su razlike uočene za olovo u krvi odnosno ALAD s visokim omjerom izgleda (14.64 odnosno 7.23), a također za relativni rizik (4.18 odnosno 3.08). Naši podaci potvrđuju povezanost između profesionalne izloženosti olovu i abnormalnih nalaza specifičnih biopokazatelja djelovanja olova te upućuju na ulogu profesionalne izloženosti u nastanku štetnih učinaka.

KLJUČNE RIJEČI: biopokazatelji, dehidrataza delta-aminolevulinske kiseline, izloženost, olovo u krui, toksičnost

\section{CORRESPONDING AUTHOR:}

Sašo Stoleski, $M D$

Department of Cardiorespiratory Functional Diagnostics

Institute of Occupational Health

WHO Collaborating Center

II Makedonska Brigada 43

1000 Skopje, Macedonia

E-mail: sstoleski@yahoo.com 